\title{
2
}

\section{Australia's International Human Rights Law Obligations}

\section{Introduction}

Australia has chosen to become a party to a number of international treaties that impose international legal obligations on Australia relating to how prisons are managed. In a federation where prisons are the responsibility of the states and territories (resulting in eight different correction laws and prison systems), the international obligations hold particular significance for ensuring consistent and equal protections across the country.

It is important to note at the outset that there is no international prohibition against imprisonment. International human rights law accepts that states may use imprisonment as a sanction. However, when people are deprived of their liberty in prisons, it does require that they only be 'deprived ... in accordance with such procedure as are established by law'. ${ }^{1}$ Therefore, the treaties concern the regulation of imprisonment, rather than preventing states from imprisoning people.

1 International Covenant on Civil and Political Rights, opened for signature 19 December 1966, 999 UNTS 171 (entered into force 23 March 1976) art 9 ('ICCPR'). 
The United Nations Basic Principles for the Treatment of Prisoners (1990), while containing 'soft' law obligations, is also relevant to understanding the international law position in relation to imprisonment. ${ }^{2}$ Principle 5 states:

Except for those limitations that are demonstrably necessitated by the fact of incarceration, all prisoners shall retain the human rights and fundamental freedoms set out in the Universal Declaration of Human Rights, and, where the State concerned is a party, the International Covenant on Economic, Social and Cultural Rights, and the International Covenant on Civil and Political Rights and the Optional Protocol thereto, as well as such other rights as are set out in other United Nations covenants.

This means that-according to international law-prisons must operate in such a way that all rights, other than the right to liberty (which is necessarily restricted by incarceration), are retained and respected. This is sometimes described as the 'residuum principle'. This principle is that a person sentenced to imprisonment retains all their rights other than those unavoidably lost by virtue of their imprisonment, such as liberty. ${ }^{3}$

Once Australian people are imprisoned, the most relevant international treaties that regulate their rights for the duration of their sentence are the International Covenant on Civil and Political Rights (ICCPR), Convention against Torture and Other Cruel, Inhuman or Degrading Treatment or Punishment (CAT) and Convention on the Rights of Persons with Disabilities (CRPD). ${ }^{4}$ The last of these three has particular relevance to Australia given the high proportion of the Australian prison population with mental illness and disabilities (as outlined in Chapter 1).

2 'Soft' law is a term used to describe international agreements that have not been negotiated as treaties and are, therefore, not covered by the Vienna Convention on the Law of Treaties, opened for signature 23 May 1969, 1155 UNTS 331 (entered into force 27 January 1980). See further Harmut Hillgenberg, 'A Fresh Look at Soft Law' (1999) 10(3) European Journal of International Law 499.

3 Bronwyn Naylor 'Protecting the Human Rights of Prisoners in Australia' in Paula Gerber and Melissa Castan (eds), Contemporary Perspectives on Human Rights Law in Australia (Lawbook Co, 2013) 396. This principle is also recognised at common law: Raymond $v$ Honey [1983] 1 AC 1, 10 (Lord Wilberforce).

4 ICCPR. Australia ratified the ICCPR on 23 November 1980. Convention against Torture and Other Cruel, Inhuman or Degrading Treatment or Punishment, opened for signature 10 December 1984, 1465 UNTS 85 (entered into force 26 June 1987) ('CAT'). Australia ratified the CAT on 10 December 1985. Convention on the Rights of Persons with Disabilities, opened for signature 30 March 2007, 2515 UNTS 3 (entered into force 3 May 2008) ('CRPD'). Australia ratified the CRPD on 17 July 2008. 
This chapter focuses firstly on Australia's international obligations under these three treaties and the other relevant international instruments that provide additional details about their operation, and secondly on the international enforcement mechanisms that are in place to support their implementation.

The domestic incorporation of some of the human rights protections contained in the international treaties is considered separately in Chapter 5. The impact of the international monitoring regime introduced by the Optional Protocol to the Convention against Torture and Other Cruel, Inhuman or Degrading Treatment or Punishment (OPCAT) on Australia is discussed in detail in Chapter 3.

\section{Treaty and Other International Law Requirements}

There are three main categories of international law. The first- treatiescontain binding legal obligations that state parties agree to when they sign up to a treaty. The second are the so-called 'soft' law obligations referred to in the introduction above that help elaborate the treaty requirements. The third is the General Comments issued by the treaty monitoring bodies (TMBs), which also elaborate the treaty requirements, given that these bodies are responsible for interpreting the treaties.

\section{Treaty Requirements}

The treaty requirements that apply to Australian prisons are overlapping and interwoven. That is, while each treaty has a distinct emphasis, they also simultaneously reinforce the requirements in the other treaties.

The three most relevant provisions of the ICCPR addressing the treatment of people once they are imprisoned ${ }^{6}$ are:

5 Optional Protocol to the Convention against Torture, adopted 18 December 1992, UN Doc A/ RES/57/199 (entered into force 22 June 2006) ('OPCAT'). Australia signed the OPCAT on 19 May 2009 and ratified it on 15 December 2017.

6 Article 9(1) of the ICCPR (referred to in the introduction to this chapter) is relevant to the circumstances under which a person is sentenced to imprisonment, rather than what occurs once they are in prison. It provides that ' $[\mathrm{n}] \mathrm{o}$ one shall be deprived of his [sic] liberty except on such grounds and in accordance with such procedure as are established by law'. 
1. art 7, which provides that ' $\mathrm{n}] \mathrm{o}$ one shall be subjected to torture or to cruel, inhuman or degrading treatment or punishment" ${ }^{7}$

2. art 10(1), which provides that '[a]ll persons deprived of their liberty shall be treated with humanity and with respect for the inherent dignity of the human person'

3. art 10(3), which provides that ' $[t]$ he penitentiary system shall comprise treatment of prisoners the essential aim of which shall be their reformation and social rehabilitation'.

Other relevant rights provided for in the ICCPR include the right to life (art 6(1)), the right to personal security (art 9(1)), the right to privacy (art 17(1)), the right to culture and religion (arts 18 and 27), ${ }^{8}$ and the right to equality before the law and not to be discriminated against (art 26). There is also a prohibition against 'arbitrary or unlawful interference' with family and correspondence that is relevant to imprisoned people's contact with their family members (arts 17 and 23), and a requirement that those on remand be separated from those who have been convicted and be treated 'appropriate to their status as unconvicted' (art 10(2)(a)).

The CAT elaborates on art 7 of the ICCPR by providing a more detailed definition of torture. ${ }^{9}$ It also requires state parties to:

- ensure torture is an offence under domestic criminal law ${ }^{10}$

- take 'effective legislative, administrative, judicial or other measures to prevent acts of torture in any territory under its jurisdiction'11

7 The Bill of Rights 1689 still applies in the states and territories, and Article 10 of that Bill is roughly equivalent to Article 7 of the ICCPR, providing, ' $[t]$ hat excessive baile ought not to be required nor excessive fines imposed nor cruel and unusual punishments inflicted'. Although the Bill of Rights has continued application, and has formed the basis of litigation as recently as the 1990s (see, eg, Holden $v$ South Australia (1992) 62 A Crim R 308), it has not provided any relief to imprisoned people in Australia. See further the discussion in Matthew Groves, 'Administrative Segregation of Prisoners: Powers, Principles of Review and Remedies' (1996) 20 Melbourne University Law Review 639, 654-8.

8 The United Nations Declaration on the Rights of Indigenous Peoples (a resolution adopted by the United Nations General Assembly on 13 September 2007) elaborates on the rights of Indigenous people to culture, religion and language contained in art 27 of the ICCPR (eg, arts 11 and 18). For a discussion of the relevance of art 27 to Indigenous people in Australian prisons see Emma Henderson and Nicole Shackleton 'Minority Rights Advocacy for Incarcerated Indigenous Australians: The Impact of Article 27 of the ICCPR' (2016) 41(4) Alternative Law Journal 244.

9 CAT art 1.

10 Ibid art 4. This requirement was implemented in Australia with the passage of the Crimes Legislation Amendment (Torture Prohibition and Death Penalty Abolition) Act 2010 (Cth).

11 CAT art 2. 
- 'undertake to prevent in any territory under its jurisdiction other acts of cruel, inhuman or degrading treatment or punishment which do not amount to torture'12

- ensure that personnel involved in imprisonment be trained about the prohibition of torture. ${ }^{13}$

The CRPD echoes the prohibition of torture and cruel, inhuman, and degrading treatment and punishment found in other treaties (art 15), as well as protecting the rights to privacy (art 22), and home and family (arts 22 and 23). Its definition of people with 'disabilities' includes 'those who have long-term physical, mental, intellectual or sensory impairments. ${ }^{14}$ As outlined in Chapter 1 , there is a high prevalence of mental illness and cognitive disability among the people in Australian prisons, meaning many would meet this definition. It may be seen from the discussion about individual communications (below) that the CRPD is becoming increasingly relevant because there have been more successful individual communications concerning Australian prison conditions brought under the CRPD than the ICCPR.

\section{Optional Protocol to the Convention Against Torture}

It can be seen from the above that there is a particular emphasis in all three Treaties on prohibiting torture, cruel, inhuman or degrading treatment or punishment. There is a particularly important international mechanism for ensuring the prevention of torture, cruel, inhuman or degrading treatment or punishment, set out in the OPCAT. The OPCAT establishes a comprehensive system for international and national inspection of places where people are deprived of their liberty and may be at risk of being subjected to 'torture and other cruel, inhuman or degrading treatment or punishment'. ${ }^{15}$ Places of deprivation of liberty include, but are not limited to, prisons. ${ }^{16}$

\footnotetext{
12 Ibid art 16.

13 Ibid art 10(1).

14 CRPD art 1.

15 OPCAT art 1.

16 The definition of 'deprivation of liberty' in the OPCAT is broad and as follows: 'any form of detention or imprisonment or the placement of a person in a public or private custodial setting which that person is not permitted to leave at will by order of any judicial, administrative or other authority': art $4(2)$.
} 
The dual levels of international and national monitoring are carried out by:

1. the international Subcommittee for the Prevention of Torture and Other Cruel, Inhuman or Degrading Treatment or Punishment (SPT), which is a United Nations (UN) committee of experts and a subcommittee of the Committee against Torture

2. the domestic National Preventive Mechanisms (NPMs) that state parties are required to establish. ${ }^{17}$

In addition to carrying out inspections of places of detention and making recommendations to states, the SPT is required to 'advise and assist' states with the establishment of NPMs. ${ }^{18}$ Once established, NPMs are required to regularly inspect places of detention and make recommendations to relevant authorities to 'improve treatment and conditions' therein. ${ }^{19}$

Australia signed the OPCAT on 19 May 2009 and ratified it on 15 December 2017. ${ }^{20}$ Between these dates it took two major steps to prepare for ratification. These were (1) the preparation of a National Interest Analysis and (2) consideration of that document by the Joint Standing Committee on Treaties, which recommended Australia ratify the OPCAT. ${ }^{21}$ Australia has three years from the date of ratification to set up an NPM. ${ }^{22}$ The Australian Human Rights Commission has been carrying out consultations to inform its advice to the government about how OPCAT should be implemented. ${ }^{23}$

17 National Preventive Mechanisms (NPMs) are required to be designated within one year of ratification: OPCAT art 17 . This period may be extended if a state party makes a declaration pursuant to art 24, which Australia has done.

18 OPCAT art 11.

19 Ibid art 19.

20 Minister for Foreign Affairs and Attorney-General (Cth), 'Ratification of OPCAT Caps Year of Significant Human Rights Achievements for Turnbull Government' (Media Release, 15 December 2017). For a detailed discussion of Australia's 'path' to ratification see Richard Harding, 'Australia's Circuitous Path Towards the Ratification of the OPCAT, 2002-2017: The Challenges of Implementation' (2019) 25(1) Australian Journal of Human Rights 4.

21 See Bronwyn Naylor, 'Protecting Human Rights in Detention. Rights, Monitoring and OPCAT' (2016) 41(3) Alternative Law Journal 151, 153-4.

22 Australia has made a declaration pursuant to art 24 of the OPCAT which allows state parties to postpone establishment of an NPM for up to three years.

23 Australian Human Rights Commission, OPCAT: Optional Protocol to the Convention Against Torture <https://www.humanrights.gov.au/our-work/rights-and-freedoms/projects/opcat-optionalprotocol-convention-against-torture>. 
With Australia's federal structure, and split responsibility for places of deprivation of liberty between Commonwealth, state and territory governments, ${ }^{24}$ it has been apparent since Australia first signed up to OPCAT that more than one organisation may be needed to form an NPM with the necessary coverage. ${ }^{25}$ Some countries have multiple organisations comprising their NPM. ${ }^{26}$

The Attorney-General has announced that multiple bodies at the federal, state and territory level will form Australia's NPM, and that the Commonwealth Ombudsman will perform the coordinating role as well as being the NPM for places of deprivation of liberty under the Commonwealth's jurisdiction (eg, immigration detention centres). ${ }^{27}$ The Ombudsman's formal role commenced on 1 July 2018. ${ }^{28}$ Western Australia has announced that the Office of the Inspector of Custodial Services (OICS) will be the NPM responsible for prisons in that state (as well as other justice system places of deprivation of liberty, such as police cells). ${ }^{29}$ Other states and territories have not yet nominated the organisations that they wish to form part of the NPM.

The OPCAT represents a significant change to the monitoring landscape in Australia, which has until now been primarily characterised as reactive, rather than preventive. The changes to the current system of prison monitoring will be explored in detail in Chapter 3. It is nevertheless important to note here that the OPCAT would add the following to the current system:

24 The Commonwealth Ombudsman identified 55 existing organisations in a 'baseline assessment' of the current monitoring of places of deprivation of liberty around Australia: Commonwealth Ombudsman, Commonwealth Ombudsman Implementation of the Optional Protocol to the Convention Against Torture and Other Cruel, Inhuman or Degrading Treatment or Punishment (OPCAT) Baseline Assessment of Australia's OPCAT Readiness Report No. 3/2019 (September 2019) 2.

25 For example, in 2010, Harding and Morgan proposed that there be a central coordinating organisation at the national level (such as the Australian Human Rights Commission), with one organisation in each state and territory: Richard Harding and Neil Morgan, 'OPCAT in the AsiaPacific and Australasia' (2010) 6(2) Essex Human Rights Review 99, 120.

26 New Zealand has five and the United Kingdom has 18. However, McGregor has argued that New Zealand may achieve better implementation of OPCAT with a single NPM: Judy McGregor, 'The Challenges and Limitations of OPCAT National Preventive Mechanisms: Lessons From New Zealand' (2017) 23(3) Australian Journal of Human Rights 351. See further in relation to New Zealand Natalie Pierce, 'Implementing Human Rights in Closed Environments: The OPCAT Framework and the New Zealand Experience' in Bronwyn Naylor, Julie Debeljak and Anita Mackay (eds), Human Rights in Closed Environments (Federation Press, 2014) 154. For a discussion of NPM models in federations see Ben Buckland and Audrey Olivier-Muralt, 'OPCAT in Federal States: Towards a Better Understanding of NPM Models and Challenges' (2019) 25(1) Australian Journal of Human Rights 23.

27 Commonwealth Ombudsman, above n 24, 1.

28 Ibid.

29 The Western Australian Ombudsman will also have NPM responsibilities: ibid 30. 
1. international-level scrutiny by an expert committee (the SPT) that may compare the situation in Australian places of detention to that in comparable jurisdictions

2. improved standards of monitoring because NPMs would need to comply with the criteria established under the OPCAT ${ }^{30}$

3. additional coverage of prison-related environments that are not currently monitored by existing monitoring mechanisms, such as vehicles transporting people between prisons ${ }^{31}$

4. comprehensive coordination and oversight at the national level (by the Commonwealth Ombudsman) that would identify gaps and overlaps in monitoring coverage that occur currently within individual places of detention, across different places of detention and across jurisdictions

5. a clear division of responsibility between organisations comprising the NPM in relation to places of deprivation of liberty, rather than the overlapping responsibility that exists currently across places of detention

6. the capacity to compare what is happening in the same environments across the different jurisdictions (eg, to compare prisons in Queensland with prisons in South Australia), which does not occur currently due to each monitoring organisation being limited to one jurisdiction

7. the capacity to compare how various types of closed environments address identical or similar human rights issues. For example, comparison of police custody and prisons, both within and across jurisdictions, and comparison of the way particular groups (such as mentally ill people) are treated across different types of environments.

The NPM offers the most potential for improving the human rights of people in Australian prisons. This is for two reasons. First, the SPT's impact will be limited because it will not visit regularly given the current resourcing levels and number of countries that have signed the OPCAT. ${ }^{32}$ Conversely, the NPM will be required to carry out regular inspections

30 It will be shown in Chapter 3 that existing organisations are not compliant with these criteria.

31 Naylor, above n 21, 154. Naylor notes that this was one of the gaps identified by the National Interest Analysis conducted in 2012. There have been deaths in prison transport vehicles in Australia, for example, the death of Mr Ward in Western Australia, which will be discussed in Chapter 3.

32 Subcommittee on Prevention of Torture and Other Cruel, Inhuman or Degrading Treatment or Punishment, Fifth Annual Report of the Subcommittee on Prevention of Torture and Other Cruel, Inhuman or Degrading Treatment or Punishment (January - December 2011) (2012). 
because this is one of the OPCAT criteria for NPM operations. ${ }^{33}$ Second, in light of the Australian Government's disregard for decisions by the TMBs (discussed later in this chapter), it remains open to question as to what the government's response would be to recommendations made by the SPT.

\section{Other Relevant Instruments}

Given the treaty obligations are abstract, there are other relevant international instruments that help to elaborate the meaning of the treaty requirements. These include the UN Standard Minimum Rules for the Treatment of Prisoners (the Nelson Mandela Rules) that were updated in 2015 and became known as the Mandela Rules, UN Rules for the Treatment of Women Prisoners and Non-Custodial Measures for Women Offenders ('the Bangkok Rules') and UN Body of Principles for the Protection of All Persons under Any Form of Detention or Imprisonment ('Body of Principles'). ${ }^{34}$ None of these constitute binding legal requirements, unlike the Treaties discussed above.

There are also General Comments issued by the relevant TMB responsible for each of the Treaties. Eastman has explained that General Comments 'offer guidance as to how the relevant human rights in the treaty should be interpreted and implemented'. ${ }^{35}$ One of the General Comments issued by the UN Human Rights Committee (HR Committee) stipulates that state parties are required to indicate in their reports to what extent they are applying the relevant United Nations standards applicable to the treatment of prisoners'. This includes the Mandela Rules and Body of Principles. ${ }^{36}$ This emphasises the importance of these instruments.

33 OPCAT art 19. This and the other criteria for NPM operations are discussed in detail in Chapter 3.

34 United Nations Standard Minimum Rules for the Treatment of Prisoners (the Nelson Mandela Rules), UN Doc A/RES/70/175 (17 December 2015) ('the Mandela Rules'); United Nations Rules for the Treatment of Women Prisoners and Non-Custodial Measures for Women Offenders, UN Doc A/RES/ 65/229 (adopted by the General Assembly on 21 December 2010) ('the Bangkok Rules').

35 Kate Eastman, 'Australia's Engagement with the United Nations' in Paula Gerber and Melissa Castan (eds), Contemporary Perspectives on Human Rights Law in Australia (Lawbook Co, 2013) 106. 36 United Nations Human Rights Committee, CCPR General Comment No. 21: Article 10 (Humane Treatment of Persons Deprived of Their Liberty) (10 April 1992) [5]. 


\section{The Mandela Rules}

The UN Minimum Rules have been in place since 1955 and have been described as 'the best-known and most widely distributed document for improving conditions of detention'. ${ }^{37}$ The updates to the Rules in 2015 took into account the wide-ranging developments in international human rights law that had occurred since the Rules were originally introduced in 1955. For example, the Mandela Rules provide specific guidance in relation to the prohibition against torture, cruel, inhuman and degrading treatment or punishment, ${ }^{38}$ whereas the 1955 Rules contained no references to torture, cruel, inhuman and degrading treatment or punishment. They also include new Rules about inspections that reflect the OPCAT requirements. ${ }^{39}$

There are a total of 122 Mandela Rules, with many of them several paragraphs long. The rules provide a lot of specific detail that aid compliance with treaty provisions and are to be read in conjunction with the General Comments issued by TMBs. For example, it has been noted that all three aforementioned Treaties prohibit 'torture, cruel, inhuman or degrading treatment or punishment'. The HR Committee has clarified that 'prolonged solitary confinement' may amount to acts within this category (as prohibited by art 7 of the ICCPR)..$^{40}$ Mandela Rule 44 provides definitions of 'solitary confinement' and 'prolonged solitary confinement' as follows: 'solitary confinement shall refer to the confinement of prisoners for 22 hours or more a day without meaningful human contact. Prolonged solitary confinement shall refer to solitary confinement for a time period in excess of 15 consecutive days'.

Due to the level of detail contained in the rules, it is not possible to catalogue all the topics covered by the rules here. Some selected examples that align with the themes that recur throughout this book are provided in Table 2.1 .

37 Katrin Tiroch, 'Modernizing the Standard Minimum Rules for the Treatment of Prisoners A Human Rights Perspective' in Max Planck Yearbook of United Nations Law, Volume 19, 2015 (Brill, 2016) 281. In the Australian context, they have been cited by Royal Commissions, including the Royal Commission into Aboriginal Deaths in Custody and the Nagle Royal Commission concerning New South Wales prisons conducted in the 1970s: Matthew Groves, 'International Law and Australian Prisoners' (2001) 24(1) University of New South Wales Law Journal 17, 27.

38 See, eg, Rules 1, 32 and 43.

39 See Rules 83-5 and discussion by Tiroch, above n 37, 295-6. See Tiroch for a detailed discussion about the process by which the Rules were updated (285-90) and the differences between the 1955 and 2015 Rules (292-304).

40 United Nations Human Rights Committee, CCPR General Comment No. 20: Article 7 (Prohibition of Torture, or Other Cruel, Inhuman or Degrading Treatment or Punishment) (10 March 1992) para 6. 
Table 2.1: Examples of the Mandela Rules

\begin{tabular}{|c|c|}
\hline $\begin{array}{l}\text { Mandela Rule number } \\
\text { and topic }\end{array}$ & Text of rule \\
\hline 12, Accommodation & $\begin{array}{l}\text { 1. Where sleeping accommodation is in individual cells or } \\
\text { rooms, each prisoner shall occupy by night a cell or room by } \\
\text { himself or herself. If for special reasons, such as temporary } \\
\text { overcrowding, it becomes necessary for the central prison } \\
\text { administration to make an exception to this rule, it is not } \\
\text { desirable to have two prisoners in a cell or room. }\end{array}$ \\
\hline 24, Health care & $\begin{array}{l}\text { 1. The provision of health care for prisoners is a State } \\
\text { responsibility. Prisoners should enjoy the same standards } \\
\text { of health care that are available in the community and } \\
\text { should have access to necessary health-care services free } \\
\text { of charge without discrimination on the grounds of their } \\
\text { legal status. } \\
\text { 2. Health-care services should be organized in close } \\
\text { relationship to the general public health administration } \\
\text { and in a way that ensures continuity of treatment and } \\
\text { care, including for HIV, tuberculosis and other infectious } \\
\text { diseases, as well as for drug dependence. }\end{array}$ \\
\hline 47, Use of restraint & $\begin{array}{l}\text { 1. The use of chains, irons or other instruments of restraint } \\
\text { which are inherently degrading or painful shall be prohibited. } \\
\text { 2. Other instruments of restraint shall only be used when } \\
\text { authorized by law and in the following circumstances: } \\
\text { (a) As a precaution against escape during a transfer, } \\
\text { provided that they are removed when the prisoner } \\
\text { appears before a judicial or administrative authority; } \\
\text { (b) By order of the prison director, if other methods of } \\
\text { control fail, in order to prevent a prisoner from injuring } \\
\text { himself or herself or others or from damaging property; } \\
\text { in such instances, the director shall immediately alert the } \\
\text { physician or other qualified health-care professionals } \\
\text { and report to the higher administrative authority. }\end{array}$ \\
\hline 52 , Bodily searches & $\begin{array}{l}\text { Intrusive searches, including strip and body cavity searches, } \\
\text { should be undertaken only if absolutely necessary. Prison } \\
\text { administrations shall be encouraged to develop and use } \\
\text { appropriate alternatives to intrusive searches. Intrusive } \\
\text { searches shall be conducted in private and by trained staff } \\
\text { of the same sex as the prisoner. }\end{array}$ \\
\hline $\begin{array}{l}76 \text {, Training of } \\
\text { prison staff }\end{array}$ & $\begin{array}{l}\text { 1. Training referred to in paragraph } 2 \text { of rule } 75 \text { shall include, } \\
\text { at a minimum, training on: } \\
\text { (a) Relevant national legislation, regulations and policies, } \\
\text { as well as applicable international and regional } \\
\text { instruments, the provisions of which must guide the } \\
\text { work and interactions of prison staff with inmates; } \\
\text { (b) Rights and duties of prison staff in the exercise of their } \\
\text { functions, including respecting the human dignity of } \\
\text { all prisoners and the prohibition of certain conduct, in } \\
\text { particular torture and other cruel, inhuman or degrading } \\
\text { treatment or punishment; } \\
\text {.. }\end{array}$ \\
\hline
\end{tabular}


The Mandela Rules (like the 1955 Rules that preceded them) are designed to be adapted to local circumstances by nations and incorporated into their national statutory schemes. ${ }^{41}$ The 1955 Rules formed the basis of the Standard Guidelines for Corrections in Australia ('Guidelines') that were adopted by the Corrections Ministers conference in 1994 and revised in 2012..$^{42}$ The Guidelines were replaced in 2018 by the Guiding Principles for Corrections in Australia ('Guiding Principles') which refer to the Mandela Rules as a 'framework' that was 'considered' in their development; ${ }^{43}$ however the Guiding Principles are seriously out of alignment with the Mandela Rules on paper, and the policies and practices in Australian prisons that are not human rights compliant increase the chasm even further. The Guiding Principles are also open to the same criticism that was made of the predecessor Guidelines, which is that they have little 'practical value' to imprisoned people and those that scrutinise prisons (such as courts and Ombudsmen) due to their non-binding nature. ${ }^{44}$

In some areas, the Guiding Principles are more out of alignment with the Mandela Rules than the predecessor Guidelines were. Three examples are given here to demonstrate this. The first is the prohibition of use of restraints during labour. The Mandela Rules are clear about this, providing that ' $[\mathrm{i}]$ nstruments of restraint shall never be used on women during labour, during childbirth and immediately after childbirth' (Rule 48(2))..$^{45}$ The Guidelines did not prohibit the use of restraints during childbirth. ${ }^{46}$ The Guiding Principles are also silent on the use of restraints during childbirth. They discourage the use of restraints during treatment for 'medical conditions', giving pregnancy as an example, but there is still discretion for restraints to be used where 'there is a serious

41 The Mandela Rules, Preliminary Observation 2 paragraph 1, noting: 'In view of the great variety of legal, social, economic and geographical conditions in the world, it is evident that not all of the rules are capable of application in all places and at all times'.

42 The Corrective Services Ministers' Conference (Cth), Standard Guidelines for Corrections in Australia (2012) 2 ('Guidelines').

43 Corrective Services Administrators' Conference (Cth), Guiding Principlesfor Corrections in Australia (2018) 6 ('Guiding Principles').

44 Matthew Groves, 'The Second Charters of Prisoners' Rights' in Matthew Groves and Colin Campbell (eds), Australian Charters of Rights a Decade On (Federation Press, 2017) 192. This conclusion is supported by Bronwyn Naylor, 'Protecting the Human Rights of Prisoners in Australia' in Paula Gerber and Melissa Castan (eds), Contemporary Perspectives on Human Rights Law in Australia (Lawbook Co, 2013) 407. The Preface to the Guidelines indicated their non-binding nature. While the Guiding Principles do not have a similar statement about their status, there is nothing to indicate that they are binding. The purpose is described to be to 'support continuous improvement and reflect the diverse challenges and priorities of correctional services in Australia': ibid.

45 This is repeated in identical terms in Rule 24 of the Bangkok Rules; thus, there can be no doubt as to the international law position on this matter.

46 Restraint is dealt with by Guidelines 1.67-1.69: Guidelines, above $n 42$. 
risk to themselves or others, a substantial risk of restraint or they cannot be restrained by any other means. ${ }^{47}$ The Department of Correctional Services in South Australia has a policy that specifically requires restraints to be used during labour, which has been repeatedly criticised by the South Australian Ombudsman since 2012 for being used irrespective of whether there was a risk of escape, but to no avail. ${ }^{48}$

Second, in relation to solitary confinement, where the Mandela Rule was referred to above, the Guidelines stipulated that 'Prolonged solitary confinement ... should not be used'; however, there was no definition of 'prolonged'. ${ }^{49}$ The Guiding Principles contain several references to 'segregation' and Principle 3.3.6 requires that a person's mental health be 'recognised and considered' where segregation is 'continued'; $;{ }^{50}$ however, there is no prohibition of prolonged solitary confinement. There is also a principle indicating that one hour per day out of cell time is sufficient and even this has a caveat of 'weather permitting. ${ }^{51}$ According to the Mandela Rule definition of 22 hours a day in a cell constituting 'solitary confinement', under the new Guiding Principles all people in Australian prisons could be subject to this.

A number of Australian jurisdictions have policies that could not be described as anything other than 'prolonged' solitary confinement. For example, in the Woodford prison in Queensland, the policy states, '[o]ut of cell time restricted to at least two daylight hours a day', leading to solitary confinement without access to daylight for 22 hours per day and falling within the Mandela Rules definition of prolonged solitary confinement. ${ }^{52}$

The third is the use of bodily searches, including strip searches. The relevant Mandela Rule (Rule 52, see Table 2.1) is clear that intrusive searches are to be 'undertaken only if absolutely necessary'. The Guidelines limited strip searching to attempts to find contraband and also required that they be

47 Guiding Principles, above n 43, Principle 3.1.16.

48 Anita Mackay, 'The Relevance of the United Nations Mandela Rules for Australian Prisons' (2017) 42(4) Alternative Law Journal 279, 284.

49 Guidelines, above n 42, Guideline 1.80.

50 Guiding Principles, above n 43, 18.

51 Ibid 12, Principle 2.3.2.

52 The policy is cited by Applegarth J in Callanan v Attendee Z [2013] QSC 342, [27]. In relation to the use of solitary confinement in Tasmania see Pickett $v$ The State of Tasmania [2011] TASSC 907 (20 April 2011) and in relation to Victoria see Dale v DPP [2009] VSCA 212 (21 September 2009). Both cases are discussed in Anita Mackay, 'Human Rights Protections for People with Mental Health and Cognitive Disability in Prisons' (2015) 22(6) Psychiatry, Psychology and Law 842, 848 and 860. 
conducted by a staff member 'of the same gender, wherever practicable..$^{53}$ The Guiding Principles provide no such restrictions on invasive searches, simply specifying that searches be carried out 'lawfully, in the least invasive manner possible..$^{54}$

The OICS has recently conducted a review of strip searching in West Australian prisons where it was found that 900,000 strip searches had been conducted in a five-year period, strip searching is routine in 97 per cent of cases (rather than dependent on risk and certainly not only carried out when 'absolutely necessary'), is sometimes used as a means of punishment or control, and causes significant distress and humiliation, particularly to people with a history of abuse. ${ }^{55}$ The OICS recommended that routine strip searching be phased out and that instead new technology be explored, ${ }^{56}$ but neither of these recommendations are supported by the government. ${ }^{57}$

\section{The Bangkok Rules}

The Bangkok Rules are explicitly intended to supplement the 1955 Rules (they predate the Mandela Rules) and there are cross-references throughout to the relevant rules that are supplemented. ${ }^{58}$ They have been made in recognition of the particular needs of women in prison that were not taken into account when the 1955 Rules were made, as well as the growth in female imprisonment rates since then. ${ }^{59}$ The relevance of both of these matters in the Australian context were detailed in Chapter 1.

There are 70 Bangkok Rules and, similar to the Mandela Rules, it is not possible to detail all of them here. However, some illustrations of the Bangkok Rules include the:

- prohibition of strip searching in Rule 20 ('alternative screening methods, such as scans, shall be developed to replace strip searches and invasive body searches, in order to avoid the harmful psychological and possible physical impact of invasive body searches')

53 Guidelines, above $\mathrm{n}$ 42, Guideline 1.55 and 1.56.

54 Guiding Principles, above n 43, Principle 2.3.12.

55 Office of the Inspector of Custodial Services (OICS), Strip Searching Practices in Western Australian Prisons (2019) iii-v.

56 Ibid xi, Recommendations 8 and 10.

57 Ibid 32-33.

58 Preliminary observation 3 states, ' 3 - The present rules do not in any way replace the Standard Minimum Rules for the Treatment of Prisoners or the Tokyo Rules and, therefore, all relevant provisions contained in those two sets of rules continue to apply to all prisoners and offenders without discrimination': the Bangkok Rules, above n 34. See also Preliminary Observation 13. 
- reference to the specific health needs that women may have that are not relevant to males in Rule 5, for example, sanitary towels

- emphasis that mothers should be able to maintain contact with their children and 'their children's guardians and legal representatives' through visits in Rule 26.

\section{Body of Principles}

Unlike the Mandela Rules, the Body of Principles applies to all forms of detention, including imprisonment. Principles 17 and 18 concern access to legal representation, Principles 19 and 20 concern contact with family members, and Principle 30 concerns disciplinary proceedings, including a requirement that review of such decisions be available. The Body of Principles also reiterate a number of treaty requirements. For example, Principle 1 requires humane treatment (echoing art 10(1) of the ICCPR) and Principle 6 prohibits torture, cruel, inhuman or degrading treatment or punishment (echoing art 7 of the ICCPR, art 1 of the CAT and art 15 of the CRPD), with Principle 33 adding to this that an imprisoned person (or their counsel) who is subject to such treatment should 'have the right to make a request or complaint ... to the authorities responsible for the administration of the place of detention and to higher authorities and, when necessary, to appropriate authorities vested with reviewing or remedial powers'.

In the same way as the provisions requiring that the rights contained in treaties be reflected in domestic legislation, Principle 7 requires that 'States should prohibit by law any act contrary to the rights and duties contained in these principles, make any such act subject to appropriate sanctions and conduct impartial investigations upon complaints'. This is not something any Australian jurisdiction has complied with, as is demonstrated in Chapter 5.

\section{General Comments}

The HR Committee (responsible for monitoring the implementation of the ICCPR) has issued a General Comment on 'Article 10 (Humane Treatment of Persons Deprived of Their Liberty)' ${ }^{60}$ The General Comment provides the following types of elaboration on the ICCPR requirements:

60 United Nations Human Rights Committee, above n 36. 
Paragraph 3 considers the interrelationship between Article 10 and the prohibition against torture, or other cruel, inhuman or degrading treatment or punishment contained in Article 7 of the ICCPR. Paragraph 4 declares that Article 10(1) is to be complied with irrespective of the material resources of the State party and 'must be applied without distinction of any kind, such as race, colour, sex, language, religion, political or other opinion, national or social origin, property, birth or other status' ${ }^{61}$

The HR Committee has also issued a General Comment on 'Article 7 (Prohibition of Torture, or Other Cruel, Inhuman or Degrading Treatment or Punishment)'. ${ }^{6}$ Paragraph 4 states, 'nor does the Committee consider it necessary to draw up a list of prohibited acts or to establish sharp distinctions between the different kinds of punishment or treatment; the distinctions depend on the nature, purpose and severity of the treatment applied' and paragraph 6 adds, '[t] he Committee notes that prolonged solitary confinement of the detained or imprisoned person may amount to acts prohibited by article 7 '.

The UN Committee against Torture (CAT/C) (responsible for monitoring the implementation of the CAT) has issued a General Comment on 'Implementation of article 2 by States parties'. ${ }^{63}$ This Comment reinforces that torture cannot be justified in any circumstances, noting in paragraph 5 that 'the prohibition against torture is absolute and nonderogable'. It goes on to emphasise that 'no exceptional circumstances whatsoever may be invoked by a State Party to justify acts of torture in any territory under its jurisdiction' (emphasis in original).

The UN Committee on the Rights of Persons with Disabilities (Disabilities Committee) has also issued a General Comment on 'equality and nondiscrimination' that mentions that prison staff should be provided with training on the rights of persons with disabilities. ${ }^{64}$

61 Anita Mackay, 'Article 10(1) of the International Covenant on Civil and Political Rights

(ICCPR) and Australian Prisons' (2017) 23(3) Australian Journal of Human Rights 368, 370.

62 United Nations Human Rights Committee, above n 40.

63 United Nations Committee against Torture, CAT General Comment No. 2 Implementation of Article 2 by States Parties (24 January 2008).

64 United Nations Committee on the Rights of Persons with Disabilities, CRPD General Comment No. 6: Equality and Non-Discrimination (26 April 2018) para 55(e). 


\section{International Enforcement Mechanisms}

There are three enforcement mechanisms in relation to the treaties that apply to imprisoned people: (1) incorporation of treaty rights into domestic law, (2) periodic reporting by the relevant TMB and (3) individual communications to the relevant TMB. ${ }^{65}$

Special Rapporteurs, which do not form part of the treaty enforcement mechanisms but are established by, and report to, the UN Human Rights Council, also visit countries that are parties to the treaties. The role of Special Rapporteurs is to 'examine, monitor, advise and publicly report on human rights situations' and ' $[t]$ hey are not bound by the terms of any particular treaty'. ${ }^{66}$

The Australian Government's response to the views of TMBs in relation to the periodic reporting process and individual communications is relevant here and is discussed near the end of this chapter.

\section{Domestic Implementation}

The Treaties impose obligations on state parties to implement the rights domestically. For example, both the ICCPR and CRPD require states 'to adopt such laws or other measures as may be necessary to give effect to the rights recognized in the present Covenant/Convention', and the ICCPR requires that there be 'effective' remedies provided. ${ }^{67}$ As noted above, the CAT requires measures to prevent torture, and the CRPD requires that 'public authorities and institutions act in conformity with the present Convention'. ${ }^{68}$

65 Of the three treaties considered here, one-the CAT-establishes a process for inter-state complaints: art 21. This is not relevant to protection of imprisoned people; therefore, this enforcement mechanism will not be discussed here. For a discussion of this mechanism see Claudio Grossman, 'Implementing Human Rights in Closed Environments Through the United Nations Convention Against Torture' in Bronwyn Naylor, Julie Debeljak and Anita Mackay (eds), Human Rights in Closed Environments (Federation Press, 2014) 141. Another enforcement mechanism not discussed here is the Universal Periodic Review, which has occurred twice for Australia (in 2011 and 2015). See Australian Government Attorney-General's Department, Australia's Universal Periodic Review <https://www.ag.gov. au/RightsAndProtections/HumanRights/United-Nations-Human-Rights-Reporting/Pages/AustraliasUniversal-Periodic-Review.aspx>; Madelaine Chiam, 'International Human Rights Treaties and Institutions in the Protection of Human Rights in Australia' in Matthew Groves, Janina Boughey and Dan Meagher (eds), The Legal Protection of Rights in Australia (Bloomsbury Publishing, 2019) 233-6.

66 Eastman, above n 35, 123. See further Surya Subedi, 'Protection of Human Rights Through the Mechanism of UN Special Rapporteurs' (2011) 33(1) Human Rights Quarterly 201.

67 ICCPR art 2; CRPD art 4.

68 CAT art 13; CRPD art 4. 
To date, Australia has not comprehensively incorporated the rights contained in these Treaties into domestic legislation. The HR Committee regularly highlights the absence of national human rights legislation in Australia. The HR Committee most recently made the following recommendation in December 2017: 'The Committee reiterates its recommendation (see CCPR/C/AUS/CO/5, para. 8) that the State party should adopt comprehensive federal legislation giving full legal effect to all Covenant provisions across all state and territory jurisdictions' ${ }^{69}$

Three Australian jurisdictions have human rights legislation (the Australian Capital Territory, Victoria and Queensland). ${ }^{70}$ However, this legislation does not incorporate all of the international human rights relevant to prisons. Specifically, art 10(3) of the ICCPR has not been incorporated by any of these jurisdictions. ${ }^{71}$ Further, in all three jurisdictions, the enforcement mechanisms provide weak protection of the rights contained therein, which arguably cannot be described as 'effective' remedies as required under the ICCPR.

Given the states and territories are responsible for prisons, there is a question about rights protection in corrections legislation around Australia. While some legislation does confer rights, these are often vague and unenforceable. ${ }^{72}$

These matters will be explored in more detail in Chapter 5 because the second prerequisite-align domestic legislation with the international human rights obligations-stems from this requirement for domestic implementation.

\section{Periodic Reporting}

The second enforcement mechanism for these Treaties is the requirement to submit periodic reports to the relevant TMB about the implementation of the treaty. These have previously been mentioned as the bodies that

69 Human Rights Committee, Concluding Observations on the Sixth Periodic Report of Australia, UN Doc CCPR/C/AUS/CO/6 (1 December 2017) 2.

70 Human Rights Act 2004 (ACT); Charter of Human Rights and Responsibilities Act 2006 (Vic); Human Rights Act 2019 (Qld).

71 It should be noted that rehabilitation does feature in the Corrections Management Act 2007 (ACT), discussed further in Chapter 6.

72 See, eg, Corrections Act 1986 (Vic) s 47; Corrections Act 1997 (Tas) s 29. 
issue General Comments, but they are the HR Committee in relation to the ICCPR, CAT/C in relation to the CAT, and Disabilities Committee in relation to the CRPD. ${ }^{73}$

Australia has provided six reports under the ICCPR (most recently in 2016, with the next one due in November 2023), six reports under the CAT (most recently on 16 January 2019) and two reports under the CRPD (a combined second and third report was submitted on 7 September 2018).$^{74}$

Following the reporting process, the relevant TMB issues Concluding Observations or Concluding Comments to which the government responds. ${ }^{75}$ The HR Committee's most recent Concluding Observations in December 2017 gave considerable attention to imprisonment, with grave concern expressed about Indigenous over-representation, followed by the concerns expressed about the treatment of people in Australian prisons: ' $[t]$ he Committee is concerned about reports of prison overcrowding, inadequate mental health-care facilities, solitary confinement and routine strip searches in places of detention (arts. 7 and 10)' ${ }^{76}$ The HR Committee made six recommendations to address these concerns, including that Australia ratify the OPCAT which, as noted above, has now been done. ${ }^{77}$ The other recommendations remain unaddressed and many are covered by the prerequisites in this book. For example, the recommendation to 'eliminate overcrowding' may be addressed by the prerequisite to reduce reliance on imprisonment. ${ }^{78}$

Other TMBs have also raised concerns about imprisonment. For example, the CAT/C has raised concerns about overcrowding in prisons, the overrepresentation of Indigenous people in prisons and inadequate health care

73 Pursuant to the ICCPR art 40, reports are required one year after the Covenant entered into force, then on request. Pursuant to the CAT art 19, reports are required every four years. Pursuant to the CRPD art 35, reports are required every four years.

74 Australian Government Attorney-General's Department, Treaty Body Reporting <https://www. ag.gov.au/RightsAndProtections/HumanRights/United-Nations-Human-Rights-Reporting/pages/ Treaty-Body-Reporting.aspx>.

75 Secretary-General of the United Nations, Compilation of Guidelines on the Form and Content of Reports to be Submitted by States Parties to the International Human Rights Treaties, UN Doc HRI/ GEN/2/Rev.5 (29 May 2008). Recent reports and responses are available at Australian Government, above $\mathrm{n} 74$.

76 Human Rights Committee, above n 69, 8.

77 Ibid.

78 Ibid [42](a). 
in prisons. ${ }^{79}$ The Disabilities Committee has raised concerns about the use of prison for accommodating people with disabilities who have not been convicted, particularly Indigenous people with disabilities. ${ }^{80}$

It should be noted, however, that Concluding Observations or Comments are not enforceable. The Australian Government's response to TMB Observations and Comments is detailed below.

\section{Individual Communications}

The third enforcement mechanism is individual communications to the relevant TMB concerning alleged violations of the rights contained in the Treaties. These communications may be made by anyone who believes their rights have been violated, including people in prison. In relation to the ICCPR and CRPD, this mechanism is provided through the ratification of the Optional Protocols. ${ }^{81}$ Under CAT, jurisdiction over individual communications is provided for in the main treaty, but state parties must 'opt in' to this jurisdiction. ${ }^{82}$ Australia opted in on 28 January 1993.

There are numerous admissibility criteria that must be established before TMBs gain jurisdiction over individual communications. ${ }^{83}$ The most difficult admissibility criterion is establishing that all domestic remedies

79 United Nations Committee against Torture, Concluding Observations of the Committee against Torture: Australia, UN Doc CAT/C/AUS/CO/3 (22 May 2008) 7.

80 United Nations Committee on the Rights of Persons with Disabilities, Concluding Observations on the Initial Report of Australia, UN Doc CRPD/C/AUS/CO/1 (21 October 2013) 4. This has also been the subject of individual communications to the Committee: see Fiona McGaughey, Tamara Tulich and Harry Blagg, 'UN Decision on Marlon Noble Case: Imprisonment of an Aboriginal Man with Intellectual Disability Found Unfit to Stand Trial in Western Australia' (2017) 42(1) Alternative Law Journal 67.

81 First Optional Protocol to the International Covenant on Civil and Political Rights, 999 UNTS 302, opened for signature 16 December 1966 (entered into force 23 March 1976). In relation to Australia's accession to this Optional Protocol see Hilary Charlesworth, 'Australias's Accession to the First Optional Protocol to the International Covenant on Civil and Political Rights' (1991) 18 Melbourne University Law Review 428; Optional Protocol to the Convention on the Rights of Persons with Disabilities, opened for signature 30 March 2007, A/RES/61/106 (entered into force 3 May 2008).

82 CAT art 21.

83 Joseph and Castan summarise the criteria under arts 1, 2, 3 and 5 of the Optional Protocol to the ICCPR to include the following: the complaint must be made by an 'individual victim', the matter must be 'within the relevant State's jurisdiction', the event that is the subject of the complaint must have occurred after the Optional Protocol was ratified, and the complaint must not be 'simultaneously before another international tribunal': Sarah Joseph and Melissa Castan, The International Covenant on Civil and Political Rights. Cases, Materials and Commentary (Oxford University Press, $3^{\text {rd }}$ ed, 2013) 19. 
have been exhausted. ${ }^{84}$ Once a communication has been considered, the TMB issues 'views on the merits', which include its conclusion as to which articles have been violated and the appropriate remedy. The state party has 180 days to report to the TMB on the steps taken to remedy any violation.

There have only been four successful communications concerning Australian prison conditions. The first was the complaint by $\mathrm{Mr}$ Brough to the HR Committee, which to date is the only successful communication brought under the ICCPR. ${ }^{85}$ At the time of the complaint, Mr Brough was a 16-year-old Aboriginal male with a mild intellectual disability who was transferred to an adult correctional facility. For some of the time he was there, he was kept in a padded isolation cell in circumstances that the HR Committee found to be in violation of arts 10(1) and 10(3) of the ICCPR. ${ }^{86}$ In making this finding, the HR Committee commented:

[i]n the circumstances, the author's extended confinement to an isolated cell without any possibility of communication, combined with his exposure to artificial light for prolonged periods and the removal of his clothes and blanket, was not commensurate with his status as a juvenile person in a particularly vulnerable position because of his disability and his status as an Aboriginal. As a consequence, the hardship of the imprisonment was manifestly incompatible with his condition, as demonstrated by his inclination to inflict self-harm and his suicide attempt. ${ }^{87}$

The other three were complaints to the Disabilities Committee under the CRPD by three Indigenous men. Mr Noble was being indefinitely imprisoned in Western Australia because he had been found unfit to

84 First Optional Protocol to ICCPR art 5(2)(b); CAT art 22(5)(b); Optional Protocol to CRPD art 2(d). This is 'unless [inter alia] there is no available remedy, or the remedy is futile': Eastman, above n $35,110$.

85 Human Rights Committee, Views: Communication No 1184/2003, UN Doc CCPR/C/86/D/ $1184 / 2003$ (17 March 2006) ('Brough v Australia'). There was a communication concerning the imprisonment of Mr Hicks for seven months following his transfer to Australia from Guantanamo Bay, which the Human Rights Committee held to be arbitrary under the ICCPR art 9(1). However, this communication did not concern the conditions of his imprisonment: see Human Rights Committee, Views: Communication No 2005/2010, UN Doc CCPR/C/115/D/2005/2010 (5 November 2015) ('Hicks v Australia'). Other communications have been found to be inadmissible, such as Human Rights Committee, Views: Communication No 762/1997, UN Doc CCPR/C/71/D/762/1997 (22 March 2001) ('Jensen v Australia').

86 The requirement for treatment with humanity and respect for human dignity, and the requirement for rehabilitation.

87 Human Rights Committee, Views: Communication No 1184/2003, UN Doc CCPR/C/86/D/ 1184/2003 (17 March 2006) ('Brough v Australia') [9.4]. 
stand trial due to his disabilities. The Disabilities Committee found that Australia's treatment of Mr Noble violated arts 5(1), 12, 13, 14(1) (b), 14(2) and 15 of the CRPD. ${ }^{88}$ This communication is discussed in detail in Chapter 7. McGaughey et al provide a succinct summary of the Committee's findings:

The Committee found that Mr Noble's right to a fair trial was fully suspended by the application of the CLMIA Act [Criminal Law (Mentally Impaired Accused) Act 1996 (WA)], depriving him of the protection and equal benefit of the law - a violation of Article 5 (1) and (2) of the Convention. They also found that the lack of support to exercise his rights to access to justice and a fair trial resulted in a violation of Articles 12 (2) and (3), and 13 (1). His detention was considered to amount to a violation of Article 14 (1) (b) which provides that 'the existence of a disability shall in no case justify a deprivation of liberty'. Finally, the Committee declared that Mr Noble's indefinite detention amounted to inhuman and degrading treatment under Article 15 of the Convention. ${ }^{89}$

The communications by Mr Leo and Mr Doolan both concerned treatment in the Northern Territory. Both men were found unfit to stand trial and were detained in the Alice Springs Correctional Centre in maximum security, with long periods in solitary confinement, for the total time of five years and 10 months and four years and nine months respectively. ${ }^{90}$ When not in solitary confinement, the men were not separated from those who had been convicted; they were subject to involuntary treatment and the supervision orders that they were subject to were indefinite. ${ }^{91}$

Similar to the views expressed in response to Mr Noble's communication, the Disabilities Committee found that arts 5, 12, 13, 14 and 15 of the CRPD had been violated by Australia in both instances. ${ }^{92}$ Also similar to the views expressed in response to Mr Noble's communication, it was the

88 Committee on the Rights of Persons with Disabilities, Views: Communication No 7/2012, UN Doc CRPD/C/16/D/7/2012 (15 August - 2 September 2016) ('Noble v Australia') [8.10].

89 McGaughey, Tulich and Blagg, above n 80, 68.

90 Committee on the Rights of Persons with Disabilities, Views: Communication No 17/2013, UN Doc CRPD/C/22/D/17/2013 (30 August 2019) ('Leo v Australia') [2.4]; Committee on the Rights of Persons with Disabilities, Views: Communication No 18/2013, UN Doc CRPD/C/22/D/18/2013

(30 August 2019) ('Doolan v Australia') [2.4].

91 Leo v Australia [8.4], [8.10]; Doolan v Australia [8.4], [8.10].

92 Leo v Australia [8.13]; Doolan v Australia [8.13]. 
indefinite detention that led the Disabilities Committee to conclude that art 15 (the prohibition of cruel, inhuman and degrading treatment and punishment) had been violated..$^{93}$

There are numerous reasons why the individual communication mechanism is not a satisfactory enforcement mechanism for the protection of imprisoned people in Australia. The first is that having to exhaust domestic remedies prior to making a communication adds to the expense and time taken for the process.

Second, although there is no requirement for parties to be legally represented to make a communication to committees, in practice, individuals may not be in a position to do so without such representation (particularly given the low educational levels among people in prison compared to the rest of the population, as discussed in Chapter 1, and the complex considerations surrounding admissibility of communications). $\mathrm{Mr}$ Noble, $\mathrm{Mr}$ Doolan and $\mathrm{Mr}$ Leo all required legal representation to bring their communications.

Third, the time taken for the TMBs to issue views on the merits is very lengthy. For example, in the Brough case, the complaint was made on 4 March 2003 and the decision was handed down on 17 March 2006. This was comparatively quick compared to the timeline for the communications to the Disabilities Committee. Mr Doolan and Mr Leo submitted their complaints on 19 September 2013 and the findings in both communications were published in October 2019.

Finally, and most importantly, there is the lack of enforceability of the views of the TMBs (detailed below). The general disregard for TMBs' views means that not only does the individual author not get redress, but a systemic change in policy or practice to prevent the same violation occurring in the future is also unlikely.

There is one positive example that goes against this general trend. This is the response to the communication concerning Tasmania's criminalisation of homosexual acts, with a penalty of 21 years imprisonment. Mr Toonen brought a communication to the HR Committee that 'alleged that the laws violated the right to privacy, distinguished between individuals in the exercise of the right to privacy on the basis of sexual activity or orientation, and amounted to the unequal treatment of homosexual men 
in Tasmania'. ${ }^{94}$ The HR Committee held that the Tasmanian law violated the right to privacy in art 17 of the ICCPR. ${ }^{55}$ The Australian Government responded by passing legislation to override the Tasmanian law, relying on the external affairs power. ${ }^{96}$

If the Australian Government were to adopt such an approach in response to communications concerning state and territory prison systems, it would lead to reform resulting from individual communications to TMB. However, this response to $\mathrm{Mr}$ Toonen's communication occurred in 1994 and it has been observed that '[s]ince Toonen, the Commonwealth Government has generally declined to intervene in what may be seen as rights-incompatible state laws'. ${ }^{97}$

\section{Visits by Special Rapporteurs}

In 2017, the Special Rapporteur on the rights of Indigenous peoples visited Australia and commented on the over-representation of Indigenous people in Australian prisons, referring to the rates as 'a major human rights concern'. ${ }^{98}$ The Rapporteur went on to note that it was having 'devastating consequences for concerned individuals and communities' and that ' $\mathrm{t}$ ] he focus urgently needs to move away from detention and punishment towards rehabilitation'. ${ }^{9}$ This recommendation supports the third prerequisite in this book, to shift the focus on imprisonment to the goal of rehabilitation and restoration (see Chapter 6).

The Special Rapporteur on violence against women, its causes and consequences also visited Australia in 2017. Three pages of the Rapporteur's report were dedicated to '[v]iolence against women in detention and against indigenous and other women in prison', expressing concern about:

94 Paula Gerber and Joel Gory, 'The UN Human Rights Committee and LGBT Rights: What Is It Doing? What Could It Be Doing?' (2014) 14 Human Rights Law Review 403, 429.

95 Human Rights Committee, Views: Communication No 488/1992, UN Doc CCPR/C/50/D/ 488/1992 (4 April 1994) ('Toonen v Australia').

96 Human Rights (Sexual Conduct) Act 1994 (Cth); Adam Fletcher, Australia's Human Rights Scrutiny Regime. Democratic Masterstroke or Mere Window Dressing? (Melbourne University Press, 2018) 37.

97 Ibid 38.

98 Human Rights Council, Report of the Special Rapporteur on the Rights of Indigenous Peoples on Her Visit to Australia, UN Doc A/HRC/36/46/Add.2 (8 August 2017) 12.

99 Ibid 14-15. These observations accord with many of the criticisms raised by the Royal Commission into Aboriginal Deaths in Custody, National Report (1991), which is discussed in detail in Chapter 3, as well as the Australian Law Reform Commission report, Pathways to Justice-An Inquiry into the Incarceration Rate of Aboriginal and Torres Strait Islander Peoples, Report No 133 (2017), which is discussed in detail in Chapter 4. 
excessive incarceration, prison overcrowding, strip-searching, solitary confinement, lack of alternatives to custodial sentences, in particular for women with dependent children, inadequate access to health care (in particular mental health care) and inadequate re-entry programmes to prevent reoffending. ${ }^{100}$

The Rapporteur reiterated the points about the vulnerability of the female prison population made in Chapter 1 of this book, particularly the rates of mental and cognitive disability and experiences of victimisation. ${ }^{101}$

\section{Australian Government Response to Treaty Monitoring Bodies}

The Australian Government is not generally inclined to accept the views of TMBs as expressed in Concluding Observations or Comments, or in views on the merits following individual communications. As the only individual communications relating to imprisonment, it is significant that the Australian Government did not accept that there had been a violation of the ICCPR in response to the views of the HR Committee in Brough, ${ }^{102}$ nor accept the findings of the Disabilities Committee in relation to the CRPD in Noble. ${ }^{103}$ There has been no government response to the communications by Mr Doolan and Mr Leo.

100 Human Rights Council, Report of the Special Rapporteur on Violence Against Women, Its Causes and Consequences on Her Mission to Australia, UN Doc A/HRC/38/47/Add.1 (17 April 2018) 11.

101 Ibid 12-13. In 2010, the Special Rapporteur on the right of everyone to the enjoyment of the highest attainable standard of physical and mental health visited Australia and his report considered health care in prisons and the over-representation of Indigenous people in prisons in Australia. This report is not discussed here because it has been superseded by the observations of Special Rapporteurs who have visited more recently. See Human Rights Council, Report of the Special Rapporteur on the Right of Everyone to the Enjoyment of the Highest Attainable Standard of Physical and Mental Health, Anand Grover, UN DOC A/HRC/14/20/Add.4 (3 June 2010).

102 See Response of the Australian Government to the Views of the Committee in Communication No $1184 / 2003$ (Brough v Australia). Charlesworth has noted that Australia's initial delay in acceding to the First Optional Protocol to the ICCPR (allowing individual communications to be brought to the Human Right Committee) was due to state and territory concern about scrutiny of the treatment of people in prisons, which adds a historical context to the reluctance to accept the Human Rights Committee's views and Australia's response to this communication concerning imprisonment: Charlesworth, above n 81, 428-9.

103 Response of the Australian Government to the Views of the Committee on the Rights of Persons with Disabilities in Communication No $7 / 2012$ (Noble v Australia). Freckelton and Keyzer note that in the response the Australian Government 'repudiated each of the Committee's findings of violation of Noble's rights': Ian Freckelton and Patrick Keyzer, 'Fitness to Stand Trial and Disability Discrimination: An International Critique of Australia' (2017) 24(5) Psychiatry, Psychology and Law 770, 776. This response relating to the findings of TCID is critiqued in Chapter 7. 
This is not atypical. ${ }^{104}$ Remedy Australia provides comprehensive monitoring of the responses to individual communications to the HR Committee, including contacting the authors of the communications about the follow-up. In a report to the UN in October 2017, Remedy Australia summarised that of the 40 communications brought between 1994 and 2017 finding violations of the ICCPR against Australia, five have been fully remedied and 10 have been partially remedied. This leaves 25 (62 per cent) that have not been remedied. ${ }^{105}$

Given there are so few communications relating to conditions in Australian prisons, it is useful to examine the government's response to cases relating to another environment in which people are deprived of their liberty, immigration detention.

Australian governments, both Coalition and Labor, have been particularly dismissive of TMBs' criticisms of the rights incompatibility of the policy of mandatory immigration detention. ${ }^{106}$ The HR Committee and CAT/C have both expressed concerns about this policy, and it has been considered in a number of individual communications. ${ }^{107}$ The government's response to the HR Committee's views on the merits in Av Australia is typical of the government's views:

[A]fter giving serious and careful consideration to the ... views of the Committee, the Government does not accept that the detention of $\mathrm{Mr} \mathrm{A}$ was in contravention of the Covenant, nor

104 For a discussion of the government's response to communications concerning preventive detention of sex offenders see Darren O'Donovan and Patrick Keyzer, "Visions of a Distant Millennium"? The Effectiveness of the UN Human Rights Petition System' in Patrick Keyzer et al (eds), Access to International Justice (Routledge, 2014).

105 Remedy Australia, Follow-Up Report on Violations by Australia of ICCPR in Individual Communications (1994-2017) (October 2017) 1. It should be noted that since this report was prepared, two of the individual communications referred to as 'unremedied' in it have been remedied by the legalisation of same-sex marriage in Australia in December 2017 (Marriage Amendment (Definition and Religious Freedoms) Act 2017 (Cth)). These are: Human Rights Committee, Views: Communication No 2216/2012, $11^{\text {th }}$ sess, UN Doc CCPR/C/119/D/2216/2012 (28 March 2017) ('C v Australia') and Human Rights Committee, Views: Communication No 2172/2012, 119 $9^{\text {th }}$ sess, UN Doc CCPR/C/119/D/2172/2012 (17 March 2017) (' $G v$ Australia'). For further details about $C v$ Australia and $G v$ Australia see Oscar Roos and Anita Mackay, 'A Shift in the United Nations Human Rights Committee's Jurisprudence on Marriage Equality? An Analysis of Two Recent Communications from Australia' (2019) 42(2) University of New South Wales Law Journal 747.

106 See further Bronwyn Naylor, Julie Debeljak and Anita Mackay, 'A Strategic Framework for Implementing Human Rights in Closed Environments' (2015) 41 Monash University Law Review 218, 229-31.

107 Human Rights Committee, above n 69, 7-8; United Nations Committee against Torture, Concluding Observations of the Committee against Torture: Australia, UN Doc CAT/C/AUS/CO/3 (22 May 2008) [11], [22], [25]. 
that the provision for review of the lawfulness of that detention by Australian courts was inadequate. Consequently, the Government does not accept the view of the Committee that compensation should be paid to $\mathrm{Mr}$ A.

The Committee is not a court and does not render binding decisions or judgments. It provides views and opinions, and it is up to countries to decide whether they agree with those views and how they will respond to them. ${ }^{108}$

In fact, it is extremely rare for the Australian Government to respond to a TMB view on the merits with law reforms, and the main instances when this has occurred have been in relation to the protection of lesbian, gay, bisexual and transgender individuals. ${ }^{109}$ Debeljak comments that this is 'despite the fact that the treaty-monitoring bodies consist of independent experts, that treaty-monitoring bodies are the authoritative voice on the application of the treaties, and that Australia voluntarily accepted the individual communication jurisdiction'. ${ }^{110}$

The HR Committee has noted the tendency for Australia to disregard its views. In Concluding Observations to Australia's recent periodic report, the HR Committee noted that they remain 'concerned (see CCPR/C/ AUS/CO/5, para. 10) about the State party's repeated failure to implement its Views'. ${ }^{111}$ The Committee had previously noted that 'a failure to give effect to its Views would call into question the State party's commitment to the First Optional Protocol'. ${ }^{112}$

108 Daryl Williams (Attorney-General) and Philip Ruddock (Minister for Immigration), 'Australian Government Responds to the United Nations Human Rights Committee' (Media Release, 17 December 1997).

109 Two communications were remedied by the legalisation of same-sex marriage in December 2017 (see above n 105), as was an earlier communication concerning Tasmanias legislation that criminalised consensual homosexual acts by adults when this legislation was repealed in 1997 by the Criminal Code Amendment Act 1997 (Tas) (Toonen v Australia). However, Chiam observes that the legalisation of same-sex marriage was 'a result of domestic political imperatives', rather than an attempt to respond to the Human Rights Committee, further noting that 'Australia's response to the Committee in that claim was drafted in a way that did not accept any finding of violation on Australia's part': Chiam, above n 65, 241.

110 Julie Debeljak, 'Does Australia Need a Bill of Rights?' in Paula Gerber and Melissa Castan (eds), Contemporary Perspectives on Human Rights Law in Australia (Lawbook Co, 2013) 54 (emphasis in original).

111 Human Rights Committee, above n 69, 2.

112 Human Rights Committee, Concluding Observations of the Human Rights Committee: Australia, UN Doc CCPR/C/AUS/CO/5 (7 May 2009) [10]. In 2017, the Committee recommended: 'The State party should promptly and fully implement all pending Views adopted by the Committee so as to guarantee the right of victims to an effective remedy when there has been a violation of the Covenant, in accordance with article 2 (3) of the Covenant': ibid 2 [10]. For further discussion about the TMB's views of Australia's attitude towards them see Chiam, above n 65, 243-4. 
In addition to this dismissive response following individual communications, the Australian Government has been equally dismissive of other TMB enforcement mechanisms. An example of this is the response to criticism by the Committee on the Elimination of Racial Discrimination concerning, among other things, amendments to the Native Title Act 1993 (Cth). ${ }^{113}$ In a response that in many ways mimics the response to the decision in Av Australia (see above)- that the committee is 'not giving binding decisions or judgments'-the then government 'rejected the views of the treaty-monitoring body in no uncertain terms'. ${ }^{114}$

In summary, while there are comprehensive human rights protections for imprisoned people at the international level, the lack of domestic incorporation, weak enforceability mechanisms and the Australian Government's reluctance to accept the views of TMBs mean there are major deficiencies in the actual protection of the human rights of Australian imprisoned people by international law.

\section{Conclusion}

International human rights law establishes that people in prison retain all their rights other than the right to liberty; prohibits 'torture, cruel, inhuman or degrading treatment or punishment'; requires that people 'be treated with humanity and with respect for the inherent dignity of the human person'; and specifies that the goal of imprisonment should be rehabilitation.

Although these are Australia's international legal obligations, there are no effective international enforcement mechanisms. Indeed, the Australian Government often ignores the expert views of TMBs in response to periodic reports and individual communications. While these are nonbinding at the international level, for states committed to implementing their human rights obligations, they provide a useful mechanism for identifying areas that should be addressed to ensure human rights compliance.

113 Committee on the Elimination of Racial Discrimination, Decision 2(54) on Australia: Concluding Observations/Comments, UN Doc CERD/C/54/Misc.40/Rev.2 (1999) [6]-[8].

114 Debeljak, above n 110, 54. Other examples are provided by Eastman, above n 35 . 
Australia's recent ratification of the OPCAT may represent a renewed commitment to international human rights law compliance in Australian prisons, with the dual-level monitoring by the SPT and NPM. The significance of the OPCAT for monitoring is considered in the next chapter before the remaining chapters consider prerequisites for implementing the preventive focus of the OPCAT. 
This text is taken from Towards Human Rights Compliance in Australian Prisons, by Anita Mackay, published 2020 by ANU Press, The Australian National University, Canberra, Australia.

doi.org/10.22459/THRCAP.2020.02 